International Research Journal of Engineering, IT \& Scientific Research
Available online at https://sloap.org/journals/index.php/irjeis/
Vol. 7 No. 4, July 2021, pages: 107-115
ISSN: 2454-2261
https://doi.org/10.21744/irjeis.v7n4.1548

\title{
Depression and Anxiety in Learning of Children and Adolescents
}

\author{
Mayra Patricia Santana Moreira ${ }^{a}$ \\ Luis Alberto Vera Espinoza ${ }^{\text {b }}$ \\ Freddy Daniel Magallanes Manzaba ${ }^{c}$ \\ Ligia Lisseth Resabala Chávez ${ }^{\mathrm{d}}$
}

\section{Article history:}

Submitted: 9 February 2021

Revised: 18 March 2021

Accepted: 27 April 2021

\section{Keywords:}

anxiety;

depression;

psychological disorders;

teaching-learning process;

\begin{abstract}
The purpose of the research is to analyze the impact that psychological disorders such as depression and anxiety have on the education of children and adolescents. This subject is valued in the educational field where the need arises to know the different causes and consequences of this problem to carry out educational practices according to the needs of the students. Several scientific theories obtained through the documentary bibliographic review are exposed, making comparisons based on opinions from different reliable sources, applying the qualitative approach, allowing relationships between different areas from the macro to what happened at the national level and the local context where the events take place students. The results determined the importance of communication between the family of students with depression and anxiety with the educational community, to jointly plan actions for the benefit of students.
\end{abstract}

International research journal of engineering, IT \& scientific research (C) 2021. This is an open access article under the CC BY-NC-ND license (https://creativecommons.org/licenses/by-nc-nd/4.0/).

Corresponding author:

Moreira, M. P. S.

Pontificia Universidad Católica del Ecuador, Portoviejo, Manabí, Ecuador

Email address: msantana7549@pucesm.edu.ec

${ }^{a}$ Pontificia Universidad Católica del Ecuador, Portoviejo, Manabí, Ecuador

b Pontificia Universidad Católica del Ecuador, Portoviejo, Manabí, Ecuador

c Pontificia Universidad Católica del Ecuador, Portoviejo, Manabí, Ecuador

d Pontificia Universidad Católica del Ecuador, Portoviejo, Manabí, Ecuador 


\section{Introduction}

Depression and anxiety are individual psychological disorders that generally affect a large number of people, causing in them low self-esteem, feelings of worthlessness, sadness and despair. It differs from normal sadness, because the individual plunges into a state of deep hopelessness without justification and anxiety dominates the person, leaving them unable to control themselves.

Internationally, it is estimated that 851 million people have some type of mental disorder, which includes problems of neurotic disorder, affective disorders, mental retardation, epilepsy, dementia, schizophrenia, anxiety and depression, constituting around 15\% of the global burden of diseases and according to data cited by the Colombian Ministry of Health, it is considered that in the coming years depression will be one of the biggest mental health problems in the world (Pardo, Sandoval, \& Umbarila, 2004). The World Health Organization (WHO) states that not attending to the mental health of a person in the early stages of life can cause mental disorders, according to the Pan American Health Organization in Latin America and the Caribbean there are approximately 17 million of children who have psychiatric problems, which are not adequately cared for (Ospina, Hinestrosa, Paredes, \& Granados, 2011).

In the United States, statistics show that women are the ones who most tend to suffer from depressive disorders in their lives, resulting in 21.3\% women and $12.7 \%$ men (Blazer, Kessler, McGonagle \& Swartz, 1994) cited by (Cassano \& Fava, 2002). The WHO indicated that mental health is essential to externalize the collective and individual capacity to think, express feelings and emotions, interact with others, work and enjoy life. There are social, psychological and biological reasons that can affect it, among them, the socioeconomic situation, poverty, low educational level, a stressful job, experiencing gender discrimination, violence and violation of human rights. Mental health problems are also determined by genetic factors that produce biochemical imbalances in the brain (WHO, 2018).

It has been determined that the high percentages of depression can be a consequence of socioeconomic and political factors, which cause unemployment, poverty, violence and hopelessness in people (Gómez \& Rodríguez, 1997). In the United States, a study was carried out which considers that between $12 \%$ and $22 \%$ of adolescents under 18 years of age have experienced some type of mental disorder, one third is likely to present a second problem during their life. Research shows that adolescents are the most vulnerable to suffering depression in their development stage, where they begin to show physical, psychological, sociocultural and cognitive changes, adopting a different personality (Pardo, Sandoval, \& Umbarila, 2004). In Colombia in 2004, in the department of well-being of the Industrial University of Santander, it was demonstrated that anxiety is one of the most attended disorders within the student population during the school stage. At the Universidad Pontificia Bolivariana de Bucaramanga, it was also investigated that in June 2005, 17\% of the students had anxiety problems and $12 \%$ had depressive symptoms (Agudelo, Casadiegos, \& Sánchez, 2008; Faravelli et al., 2013; Kurki et al., 2000).

In Mexico City, it was established that approximately four million people, which constitutes $9.2 \%$ of the population, have some type of symptom related to depression (Vargas, Villareal, Guevara, \& Andrade, 2014). Depressive disorders cause different degrees of disability, can affect physical, mental or social functions and are currently associated with a higher risk of death at an early age. In some cases they can make it impossible for the person to carry out their daily activities, causing a significant deterioration in their normal functioning and quality of life.

In Ecuador, many parents believe that mental illness is not a disease, but a weakness in character; They think that the will should be the sufficient factor to control their emotions and in some cases they try to hide it, this situation harms the individual. Currently, the country has 5 hospitals and psychiatric clinics, only two are public, the rest are private, this infrastructure is insufficient given the need for people with mental disorders. Situation that aggravates the opportunity to access this health service due to lack of money, because the costs are really high.

The Ministry of Labor of Ecuador has a program to prevent social risks, which is basically a tool, in which through different tests they evaluate the emotional and psychological state of each employee, in order to prevent and diagnose in time, those that are emotionally unstable whether they belong to the public or private sector, ensuring adequate treatment as appropriate, this tool is not mandatory. In the Ecuadorian education system, there have been constant cases of children with attention problems in the teaching-learning process, which are caused by specific disorders, such as depression and anxiety (Salazar, 2018). Education is a basic aspect, which guarantees the training of children and adolescents in a comprehensive manner, providing them with quality and warmth, within an inclusive environment, where everyone plays a fundamental role within the teaching-learning process (Calderón, 2019; Javnbakht et al., 2009; Spoormaker \& van den Bout, 2005). 
There is no Mental Health Law, but in several legal bodies very clear provisions are specified on various aspects of the psychological health of Ecuadorians, requiring a link or coordination between the bodies in charge of monitoring human rights and the health care facilities. health (Report on the Mental Health System of Ecuador, 2007). In preadolescence, depression affects both boys and girls in the same proportion and in some cases increases with age. According to several studies, upon reaching puberty, the risk increases in girls, in such a way that they require greater care, especially in late adolescence, where they are 2 to 3 times more likely to be affected compared to boys (Moreno, Escobar, Vera, Calderón, \& Villamizar, 2009; Kroenke et al., 2009; Skouteris et al., 2009).

The training that minors receive at home and external factors may be responsible for the development of possible depressive symptoms; Among them are the contexts where they live, the relationships with the group of peers at school, the family environment, the lack of continuous dialogue, the strong use of punishment, the failure to provide adequate stimulation based on the achievements that reach the child or adolescent, these can generate psychopathologies and turn the family into a predisposing factor for them. The dynamics that occur in these contexts, the infinity of variables that can intervene in the development of a disorder, are in a certain way related to how the subject adapts to his environment and how it relates to him to achieve a correct performance.

\section{Materials and Methods}

The research is of a documentary type, based on the search, retrieval, analysis, criticism and interpretation of secondary information, obtained and recorded by other researchers. By using this type of design, the purpose is to contribute new knowledge and put it at the service of society (Arias, 2006). The procedure used to obtain information was the documentary analysis, where information available on websites, repositories and indexed journals was downloaded and analyzed, which constituted the primary and secondary sources of the investigation. (Gomez, 2010).

The applied approach was qualitative, where questions and hypotheses were developed before, during and after data collection and analysis. The investigative action was carried out dynamically in both directions: between the facts and the interpretation, a circular process results in which the sequence is not always the same, as it varies with each study. Next, the scheme of this approach is represented in figure 1.

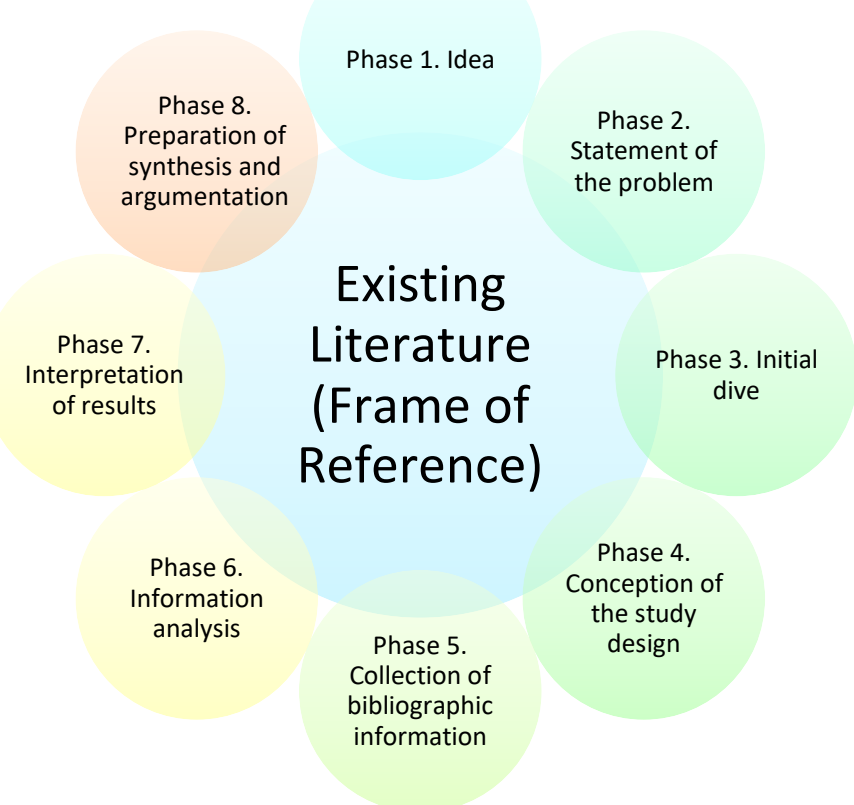

Figure 1. Scheme of the phases of the qualitative approach

Source: (Hernández, Fernández, \& Baptista, 2014)

Moreira, M. P. S., Espinoza, L. A. V., Manzaba, F. D. M., \& Chávez, L. L. R. (2021). Depression and anxiety in learning of children and adolescents. International Research Journal of Engineering, IT \& Scientific Research, 7(4), 107-115. https://doi.org/10.21744/irjeis.v7n4.1548 
The inductive-deductive method was used to extract conclusions logical, valid and concrete based on a set of premises, going from the general to the more specific and vice versa. It has a descriptive scope where the phenomena, situations, contexts and events related to the subject are synthesized, how they are and how they are manifested are detailed, which has allowed to collect information independently on the concepts or variables to which they refer (Sampieri, Collado, Lucio, Valencia, \& Torres, 1998)

\section{Results and Discussions}

There are diseases that influence health in contemporary times, depression and anxiety occur in a large number of people mainly affecting children and adolescents, these generally do not express their feelings, but they show it in their moods, it can be identified when they drop their academic performance, withdraw from society or commit inappropriate acts

\section{Depression}

It is determined as a disease of continuous prevalence in this century, an average of more than 350 million of people, which represents $4.4 \%$ of the world's population. It is defined as a disturbance of affectivity, mood and humor, manifested by biological, psychological and environmental stimuli. The appearance of depression in the life of a child occurs in a comorbid way, producing anxiety, complaints, irritability and poor academic performance, which causes the infant or adolescent to isolate himself from relationships with other individuals, it can also be identified in people who have a negative view of themselves and everything that surrounds them (Vargas, Villareal, Guevara, \& Andrade, 2014).

\section{Anxiety}

It is an emotion, which is generally a normal and healthy reaction, it activates the body to respond quickly, everyone has experienced it at some point, it produces a psychophysiological change of rapid activation of the central nervous system and the entire organism. It is activated when the individual needs to act in a scenario that requires an acute or incessant effort and activate the mechanisms to face a threat or danger that occurs in the present or that may happen in the future (Forcadell, Fullana, Lázaro, \& Lera, 2019).

The problems of anxiety disorders in children and adolescents can become chronic, if they are not attended to in time, becoming a great inconvenience in physical and mental health, causing them not to lead a quality life, limiting their social development and even having difficulties in their personal and family life (Ballesteros \& Sarmiento, 2012). There are several types of disorders that they may experience, as shown in Figure 2. 


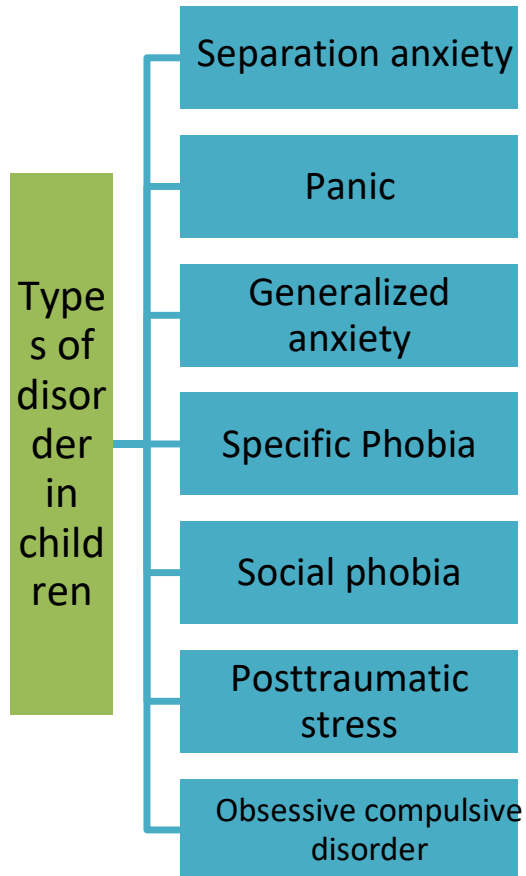

Figure 2. Types of anxiety disorders in children Source: (Sandin \& Valiente, 2009)

Many of these disorders are manifested in homes, in these times of pandemic and virtuality where children and adolescents have lost social contact and with-it activities that were carried out with their friends, resulting in intrafamily conflicts. Childhood depression manifests itself in a sadness of greater intensity than normal, the scientific community for a long time held the theory that this disorder did not exist, giving little importance to the mental health of children, however, some clinical professionals were against to this hypothesis (Navarro, 2004).

Normally children and adolescents with anxiety symptoms are first examined by a pediatrician, they generally have complaints such as abdominal pain, crying, irritation and anger, which can be misinterpreted, causing unnecessary medical studies, since for a correct diagnosis they must be referred with the relevant professional (Agudelo, Casadiegos, \& Sánchez, 2008).

There are factors that aggravate depression and anxiety in Ecuadorians, among them are the place where they live and the activities that children and adolescents carry out in their free time, the quality of housing, including the number of people with whom they share it. In $31.6 \%$ of households there is alcohol consumption, which is a very widespread habit and affects 1 in 4 adolescents before reaching 15 years of age and about $6 \%$ between 12 and 17 years of age have consumed some type of drugs. The country's economic crisis means that many minors have to contribute to the economy of their homes and neglect educational opportunities, of this group $45 \%$ between 10 and 17 years of age are incorporated into the economically active population and give their income to their parents or relatives (Morla, Saad de Janon, \& Saad, 2006).

\section{Symptoms of depression}

Depression is characterized by the fact that the person experiences feelings of worthlessness, guilt, sadness and deep hopelessness, this disorder is accompanied by symptoms such as loss or sleep disturbances, lack of appetite, selfpunishment and physical inactivity, reflecting that the subject is going through a psychological problem that is affecting him directly and individually (Flores, Jiménez, Pérez, Ramírez, \& Vega, 2007). Figure 3 shows the causes and consequences of depression in children.

Moreira, M. P. S., Espinoza, L. A. V., Manzaba, F. D. M., \& Chávez, L. L. R. (2021). Depression and anxiety in learning of children and adolescents. International Research Journal of Engineering, IT \& Scientific Research, 7(4), 107-115. https://doi.org/10.21744/irjeis.v7n4.1548 


\section{Causes}

Depressive mothers can father depressive children

Separation from parents

School, social and economic problems

Rejection by his schoolmates

Low grades

Low self-esteem

Child abuse or maltreatment

Loneliness, discrimination

Bulling

Domestic violence

\section{Consequences}

Appetite disorder

Sleep disorder

Motor agitation or decreased drive

Loss or deficiency of physical activity

Lack of energy

Guilty feeling

Poor concentration

Suicidal thoughts

Thoughts about death

Figure 3. Causes and consequences of depression.

Source: Adapted from (Navarro, 2004) and (Agudelo, Casadiegos, \& Sánchez, 2008).

There are several causes and consequences related to depression that manifest themselves in students at different levels, many of them linked to the family and their actions within the home.

\section{Treatment of depression and anxiety}

Researchers have explored pharmacotherapy to treat disorders caused by anxiety, taking into account the risksbenefits of pharmacological treatments in children and adolescents, in order to obtain and demonstrate the effectiveness of These treatments are also responsible for facing social phobias through an effective treatment, aimed at reducing the symptoms and related problems. Two steps are proposed to follow to reduce the negative effects of this disease: antidepressant medications and visits to the psychotherapist (Beck, Rush, Shaw, \& Emery, 2003), according to these authors these help to improve the difficulties caused by these pathologies.

\section{Depression and anxiety in the teaching-learning process Depression and anxiety disorders in the teaching-learning}

process manifest in different ways, for example, in slow reading or stuttering, not understanding the meaning of texts, not write correctly, problems when expressing oneself orally or in writing, difficulty in carrying out mathematical reasoning, among others (Salazar, 2018). 
To the student who affects learning difficulties, the constructive conflict resolution model should be applied, which increases social support and reduces victimization for them. Changes in students' interpersonal relationships increase self-esteem and generate positive attitudes towards life, managing to reduce depression and anxiety, favoring internal control that contributes to increasing academic achievement (Pérez \& Urquijo, 2001).

These disorders in children and adolescents can cause problems in their school performance and in the relationship they have with society, motivating them to lock themselves into their individualistic world, distancing themselves from everything around them (Andrés, Juric, Castañeiras, \& Richaud, 2016). The Attention-Deficit / Hyperactivity Disorder (ADHD) is one of the disorders in the teaching-learning process where the child presents symptoms of depression and anxiety, in addition to low self-esteem and conduct disorders (Navarro, 2004).

Childhood depression is the result of the interaction that exists between environmental and personal factors, a competent child or adolescent can make correct decisions in the face of a big problem, but a vulnerable one can be affected with small inconveniences. In all children these situations do not influence the same, for this reason, the different problems that affect the majority are faced differently, vulnerability provides information to explain how depression occurs, what factors in daily life can be negatively influencing the academic performance of children, they are withdrawn, distracted, nervous, cannot concentrate or present aggressiveness and in some cases they refuse to comply with institutional norms, they appear challenging, lacerating attitudes and others are introverted.

The cognitive model determines that one of the parts most affected by this disorder is information processing, the child or adolescent is in a constant negative view of everything that surrounds him, thus affecting the way of interpreting the information. For this reason, steps are manifested to help in the teaching-learning process of people who have this type of disorder, such as: reviewing the tasks at home and analyzing them, listing the problems and techniques to be used to solve them and finally proposing new ones tasks to be carried out at home with the help of the family or a psychopedagogue (Roca, 2012). Anxiety is a normal emotion in human beings, therefore children are not exempt from it, adults must observe those strongest episodes, depression in children or adolescents is identified when they experience feelings of extreme sadness and hopelessness that seems never finish, they lose total interest in most of the daily activities, which were previously their favorites, such as appetite, insomnia, excessive sleep, fatigue and lack of energy, lowering their academic performance.

\section{Conclusion}

Assertive communication between parents and the educational community generates a positive impact on the treatment for the improvement of this anxiety and depression disorder in children and adolescents because it is the environment where the child develops daily, achieving pedagogical adaptations that they must carry out to avoid problems in the teaching-learning process.

Anxiety and depression are disorders that appear at an early age when students cannot carry out their daily activities and there is not a good relationship between the family and the teacher, having to seek the help of professionals.

Conflict of interest statement

The author(s) declared that they have no competing interest.

Statement of authorship

The author(s) have a responsibility for the conception and design of the study. The author(s) have approved the final article.

Acknowledgments

We are grateful to two anonymous reviewers for their valuable comments on the earlier version of this paper.

Moreira, M. P. S., Espinoza, L. A. V., Manzaba, F. D. M., \& Chávez, L. L. R. (2021). Depression and anxiety in learning of children and adolescents. International Research Journal of Engineering, IT \& Scientific Research, 7(4), 107-115. https://doi.org/10.21744/irjeis.v7n4.1548 


\section{References}

Agudelo, D., Casadiegos, C., \& Sánchez, D. (2008). Characteristics of anxiety and depression in university students. International Journal of Psychological Research, 34-39. Retrieved February 19, 2021, from https://www.redalyc.org/articulo.oa?id=2990/299023503006

Andrés, M., Juric, L., Castañeiras, C., \& Richaud, M. (2016 ). Relationships of emotional regulation and personality with anxiety and depression in children. Advances in Latin American Psychology ,, 34(1), 99-115. Obtained from https://dialnet.unirioja.es/servlet/articulo?codigo $=5270385$

Arias, F. (2006). The research project. Episteme, 6, 9-43. Retrieved from https://www.researchgate.net/publication/261472513_Fidias_G_Arias_-_El_Proyecto_de_la_Investigacion

Ballesteros, M., \& Sarmiento, J. (2012). Anxiety disorders in children and adolescents. Revista Vanguardia Psicológica Clínica Teórica y Practica, 3(2), 184-195. Obtained from https://dialnet.unirioja.es/servlet/articulo?codigo $=4815155$

Beck, A., Rush, J., Shaw, B., \& Emery, G. (2003). Cognitive Therapy. Psychology Library, 1-16. Obtained from https://www.google.com/url?sa=t\&rct=j\&q=\&esrc=s\&source=web\&cd=\&cad=rja\&uact=8\&ved=2ahUKEwji53sl_fuAhXszVkKHeg2ClAQFjADegQIFxAD\&url=http2\%F2co\% www.copiados2F\%F2\% 2Fpv00520\% 2FGuia\% 2520Beck\% 2520depresion.pdf \& usg = AOvVaw2L6gwi3Y95dw4fFrQF7xn4

Calderón, C. (2019). Prevalence of school refusal in secondary education and its relationship with psychoeducational variables. $R U A, 265$. Obtained from https://dialnet.unirioja.es/servlet/tesis?codigo=220132

Cassano, P., \& Fava, M. (2002). Depression and publichealth: an overview. journal of psychosomatic research, 53, 849-857. Retrieved from https://pubmed.ncbi.nlm.nih.gov/12377293/

Faravelli, C., Scarpato, M. A., Castellini, G., \& Sauro, C. L. (2013). Gender differences in depression and anxiety: the role of age. Psychiatry research, 210(3), 1301-1303. https://doi.org/10.1016/j.psychres.2013.09.027

Flores, R., Jiménez, S., Pérez, S., Ramírez, P., \& Vega, C. (2007). Depression and Anxiety in Students. Electronic Journal of Psychology Iztacala, 10(2), 94-105. Obtained from http://www.revistas.unam.mx/index.php/repi/article/view/19112

Forcadell, L., Fullana, M., Lázaro, L., \& Lera, S. (29 de 01 de 2019). What is anxiety? Obtained from Clinic Barcelona Hospital University: https://www.clinicbarcelona.org/asistencia/enfermedades/trastornos-deansimonio/definicion

Gómez, C., \& Rodríguez, N. (1997). Risk factors associated with depressive syndrome in the Colombian population. Colombian Journal of Psychiatry, 26(1), 23-35. Retrieved from https://pesquisa.bvsalud.org/portal/resource/pt/lil-

Gomez, L. (2010). A space for documentary research. Revista Vanguardia Psicológica Clínica Teórica y Practica, 1(2), 226-233. Obtained from https://dialnet.unirioja.es/buscar/documentos?querysDismax.documental_todo=investigaci\%c3\%b3n\%20docume ntal\&filtros.documental_facet_entidad=artrev

Hernández, R., Fernández, C., \& Baptista, M. (2014). Research methodology (Sixth edition ISBN: 978-1-4562-23960 ed., Vol. 6). (ES México, Ed.) Mexico: MacGraw Hill Education Editions. Interamerican.

Javnbakht, M., Kenari, R. H., \& Ghasemi, M. (2009). Effects of yoga on depression and anxiety of women. Complementary therapies in clinical practice, 15(2), 102-104. https://doi.org/10.1016/j.ctcp.2009.01.003

Kroenke, K., Spitzer, R. L., Williams, J. B., \& Löwe, B. (2009). An ultra-brief screening scale for anxiety and depression: the PHQ-4. Psychosomatics, 50(6), 613-621. https://doi.org/10.1016/S0033-3182(09)70864-3

Kurki, T., Hiilesmaa, V., Raitasalo, R., Mattila, H., \& Ylikorkala, O. (2000). Depression and anxiety in early pregnancy and risk for preeclampsia. Obstetrics \& Gynecology, 95(4), 487-490. https://doi.org/10.1016/S00297844(99)00602-X

Moreno, J., Escobar, A., Vera, A., Calderón, T., \& Villamizar, L. (2009). Association between depression and academic performance in a group of children from the town of Usaquén. Psychology. Discipline Advances, 3(1), 131-156. Retrieved from https://www.redalyc.org/articulo.oa?id=2972/297225173007

Morla, B., Saad de Janon, E., \& Saad, J. (2006). Depression in adolescents and family breakdown in the city of Guayaquil, Ecuador. Colombian Journal of Psychiatry, 35(2), 149-166. Obtained from https://www.redalyc.org/pdf/806/80635203.pdf

Navarro, M. (2004). Depression in children with attention deficit disorder. Reflections Magazine, 83(1), 1021-1209. Obtained from https://dialnet.unirioja.es/servlet/articulo?codigo $=4796128$ 
Ospina, F., Hinestrosa, M., Paredes , MG, \& Granados, C. (2011). Symptoms of anxiety and depression in school adolescents aged 10 to 17 years in Chía, Colombia. SciELO - Scientific Electronic Library Online, 13(6), 908920. Retrieved from https://sskip.org/article/rsap/2011.v13n6/908-920/

Pardo, G., Sandoval, A., \& Umbarila, D. (2004). Adolescence and depression. Colombian Journal of Psychology, 13, 13-28. Obtained from https://revistas.unal.edu.co/index.php/psicologia/article/view/1204/0

Pérez, M., \& Urquijo, S. (2001). Depression in adolescents. Relations with academic performance. School and $\begin{array}{llll}\text { Educational } & \text { Psychology, } & \text { 59-58. } & \text { Obtained from }\end{array}$ http://pepsic.bvsalud.org/scielo.php?script=sci_arttext\&pid=S1413-85572001000100006\&lng=pt\&tlng=es.

Roca, E. (2012). Beck's Cognitive Therapy for depression. Psychology Library, 1-12. Obtained from http://www.cop.es/colegiados/PV00520/depresion6.pdf.

Salazar, Y. (2018). Sociodemographic characterization of children with specific learning disorders. Ibero-American Journal of Psychology: Science and Technology, 12(2), 1-8. Obtained from https://dialnet.unirioja.es/servlet/articulo?codigo=6734861

Sampieri, R., Collado, C., Lucio, P., Valencia, S., \& Torres, C. (1998). Investigation methodology. Mexico, DF:

$\begin{array}{lcc}\text { Mcgraw-hill, } & 1, & \text { Obtained } \\ \text { https://academia.utp.edu.co/grupobasicoclinicayaplicadas/files/2013/06/Metodolog\%C3\%ADa-de-la- }\end{array}$ Investigaci\%C3\%B3n.pdf

Sandin, B., \& Valiente, P. (2009). Evaluation of symptoms of anxiety and depression disorders in children and adolescents. Journal of Psychopathology and Clinical Psychology, 14(3), 193-206. Obtained from http://espacio.uned.es/fez/view/bibliuned:

Skouteris, H., Wertheim, E. H., Rallis, S., Milgrom, J., \& Paxton, S. J. (2009). Depression and anxiety through pregnancy and the early postpartum: an examination of prospective relationships. Journal of affective disorders, 113(3), 303-308. https://doi.org/10.1016/j.jad.2008.06.002

Spoormaker, V. I., \& van den Bout, J. (2005). Depression and anxiety complaints; relations with sleep disturbances. European psychiatry, 20(3), 243-245. https://doi.org/10.1016/j.eurpsy.2004.11.006

Vargas, C., Villareal, K., Guevara, C., \& Andrade, M. (2014). Depression and anxiety in university students. Journal of Psychology and Behavioral Sciences., 5(1), 36-44. Obtained from https://dialnet.unirioja.es/servlet/articulo?codigo=5925164

WHO. (March 30, 2018). Mental health: strengthening our response. Obtained from the World Health Organization: https://www.who.int/es/news-room/fact-sheets/detail/mental-health-strengthening-our-response

Moreira, M. P. S., Espinoza, L. A. V., Manzaba, F. D. M., \& Chávez, L. L. R. (2021). Depression and anxiety in learning of children and adolescents. International Research Journal of Engineering, IT \& Scientific Research, 7(4), 107-115. https://doi.org/10.21744/irjeis.v7n4.1548 